\title{
Epibenthic Colonization on an Artificial Reef in a Stressed Environment off the North Coast of the Rio de Janeiro State, Brazil
}

\author{
Werther Krohling and Ilana Rosental Zalmon* \\ Universidade Estadual do Norte Fluminense; Centro de Biociências e Biotecnologia; Av. Alberto Lamego, 2000. \\ Camposdos Goytacazes; ilana@uenf.br; werther@cemares.org.br; 28013-602; RJ - Rio de Janeiro - Brasil
}

\begin{abstract}
The influence of sedimentation and turbidity caused by the pluviometric precipitation and by the Paraiba do Sul River during the summer was investigated on an artificial reef along the north coast of Rio de Janeiro, Brazil. Four recruitment and four cumulative plates were removed monthly (January 2002 to February 2003) from the external surface of the concrete reef modules. Empty space was not a limiting factor the recruitment. Turnover rate and structural difference index were higher in the first months and reflected low change in the species dominance during almost the entire study period. The high correlation between the precipitation and the empty space suggested that rain influence the recruitment and the succession. The recruitment was possible despite stress factors such as sedimentation, turbidity, abrasion, strong bottom currents and a lack of natural consolidated substrate. Changes in the community structure reflected the substrate colonization history of a few resistant species and their subsequent interactions.
\end{abstract}

Key words: Recruitment, succession, benthic community structure, natural disturbance

\section{INTRODUCTION}

Benthic marine invertebrates have a dispersal larval phase that facilitates the colonization of new environments. The planktonic larvae tend to settle as soon as they find appropriate natural or artificial substrate (Connell and Glasby, 2001; Lindegarth, 2001), although the recruitment depends on the propagule or larval readiness, effect of currents, microhabitat effect (Skinner and Coutinho, 2005) and larval behavior and habitat selectivity (Underwood and Fairweather, 1985). The recruitment intensity depends on the larval production and the dispersion, mortality during the dispersion, settlement and habitat selection processes. According to Scheffer (2001), all of these factors depend on several environmental conditions. The sedimentation and turbidity can negatively interfere in the recruitment and the succession of the epibenthic species by closing and clogging their feeding and gas exchange structures (Perkins, 1974; Maughan, 2001).

The Paraiba do Sul River has a hydrographic basin of approximately $55.5 \mathrm{~km}^{2}$ including the states of São Paulo, Minas Gerais and Rio de Janeiro (Costa, 2003). The north coast of Rio de Janeiro has extensive sandy beaches with no natural hard substrate. Reduced temporal variations in the salinity, $\mathrm{pH}$, dissolved oxygen and nutrients are in contrast to a high

\footnotetext{
${ }^{*}$ Author for correspondence
} 
pluviometric precipitation and outflow of the Paraíba do Sul River with higher values in the summer months (Godoy et al., 2002). According to Figueiredo (1999), in this season there is a strong influence of the local pluviosity and Paraiba do Sul River outflows with the saline plume to a distance of about $10 \mathrm{~km}$ off the coast. Primary productivity (chlorophyll $a$ ) is low and strong bottom currents generate high abrasion. The water has a maximum transparency of $4 \mathrm{~m}$ in the summer months (Zalmon and Gomes, 2003).

The aim of this work was to test the following hypotheses: i) the seasonality in the recruitment of the epibenthic species occurred due to the temporal variation of the rainfall and Paraiba do Sul River discharge; ii) changes in the successional process were related to the substrate submersion time.

\section{MATERIALS AND METHODS}

A total of 36 reefballs, $100 \mathrm{~m}$ apart from each other were immersed $9 \mathrm{~m}$ deep, about $5 \mathrm{~km}$ away from the Manguinhos Beach on the northern coast of Rio de Janeiro (21 $29^{\prime} \mathrm{S}^{\prime}$, $41^{\circ} 00^{\prime} \mathrm{W}^{\prime}$ ) (Fig. 1).

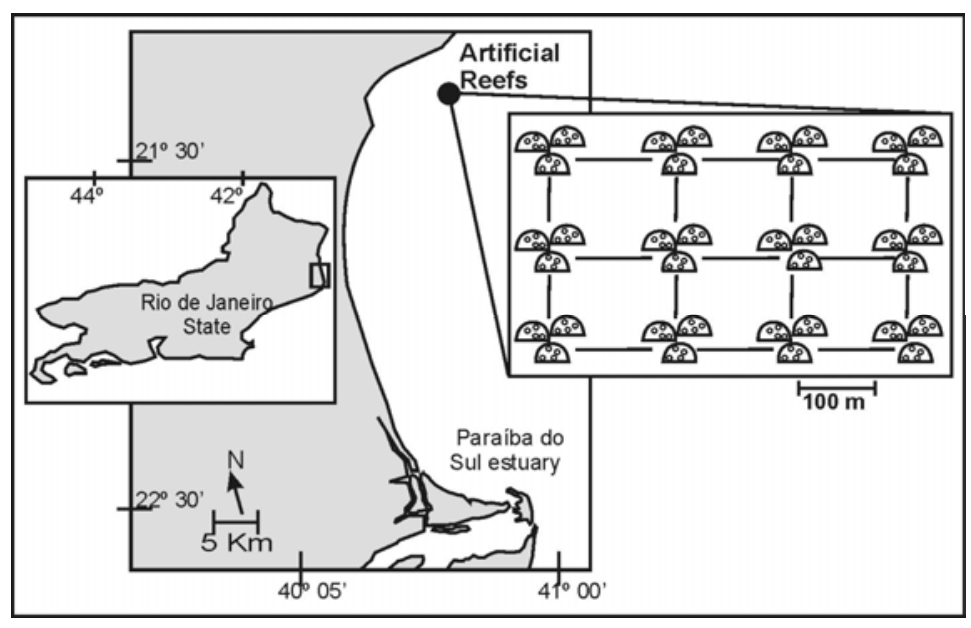

Figure 1 - Study site on the northern coast of the Rio de Janeiro state ( $21^{\circ} 29^{\prime} \mathrm{S}^{\prime}, 41^{\circ} 00^{\prime} \mathrm{W}$ ') and schematic representation of the artificial modules.

Daily registration of local pluviosity was obtained from the Climatology Department of the University Federal Rural of Rio de Janeiro $(\approx 60$ $\mathrm{km}$ from the artificial reef site). According to Figueiredo (1999), seasonal variation pattern of the pluviosity is homogeneous along the Paraiba do Sul basin but the pluviosity amount changes within the basin locality (upper: > $2000 \mathrm{~mm} /$ year, lower and estuary: $1200 \mathrm{~mm} / \mathrm{ano}$ ). Paraiba do Sul River outflow $\left(\mathrm{m}^{3} \mathrm{~s}\right)$ was measured biweekly at the city of Campos dos Goytacazes.

Concrete plates $\left(400 \mathrm{~cm}^{2}\right)$ were fixed to the external surface of each reef module. From January 2002 to February 2003, four recruitment plates (immersed monthly and removed after 30 days of submersion) and four cumulative succession plates from a total number of 48 (immersed since the beginning of the experiment) were withdrawn monthly from the distinct reef modules. To preserve the temporal sampling independence, the plates were analyzed by a destructive technique of the point-intersection to obtain the percent cover of the epibenthic organisms (Sutherland, 1974). Strong storms prevented the plate's removal in August and September 2002. The community structure descriptors were species richness, Brillouin's diversity and Simpson's dominance (Magurran, 1988; Krebs, 1989). The structural changes in the community were investigated by the turnover rate (immigration versus extinction rate) and structural difference index (Goren, 1979).

The influence of pluviosity and Paraíba do Sul River outflow on the species recruitment, and the 
relationship of the recruits between the residents were analyzed through Pearson's correlation coefficient (Zar, 1984) using monthly values of the environmental parameters and percent cover of the dominant species. The community development stages and the corresponding dominant species were examined by the Principal Component Analysis (PCA) using the mean percent cover values (Krebs, 1989).

\section{RESULTS}

The mean values of the outflow and the pluviometric precipitation in the Paraiba do Sul River reflected two seasons in the region: a rainy period mainly during the summer months (December to February) and a drier period (remaining months) (Krohling et al., 2006). After 12 months, the most abundant recruiters were Hydrozoa, Cirripedia and Polychaeta, while on succession plates Hydrozoa, Ectoprocta and Cirripedia were the most abundant. Taxa richness varied from two (October 2002) to nine (May 2002). Lower values of the diversity were recorded in October $2002(\mathrm{H}=0.8)$, due to the dominance of Balanus spp and to a large empty space. The highest diversity values were observed in April and May $2002(\mathrm{H}=1.8$ and 1.7, respectively), corresponding to a smaller dominance and a higher richness. On the cumulative plates, the species number showed an increasing slope during the study period $(\mathrm{N}=4$ to 16 species). This tendency was not evident in the diversity and the dominance values, which were relatively stable due to the early establishment of a few dominant organisms (Fig. 2).

The empty space did not appear to be limiting for species recruitment as more than $25 \%$ of the sampled surface was empty for the study. On the succession plates, less than $10 \%$ of the surface was empty after the sixth month. The dominant taxa Balanus spp, Clytia spp, Obelia spp, Ostrea $\mathrm{sp}$ and Bougainvillia sp had no definite period of colonization with irregular patterns alternating in dominance (Fig.3).

The turnover rate and the structural difference index were highest (> 40\%) during the initial months, due to the introduction of several species into the open space. A decreasing tendency in both the curves reflected the low change in the species dominance during almost entire study period. The higher values in the last two months $(40 \%)$ corresponded to the immigration of seven new species and the extinction of five others, however, all of these species were rare ( $<5 \%$ cover, Fig. 4$)$.

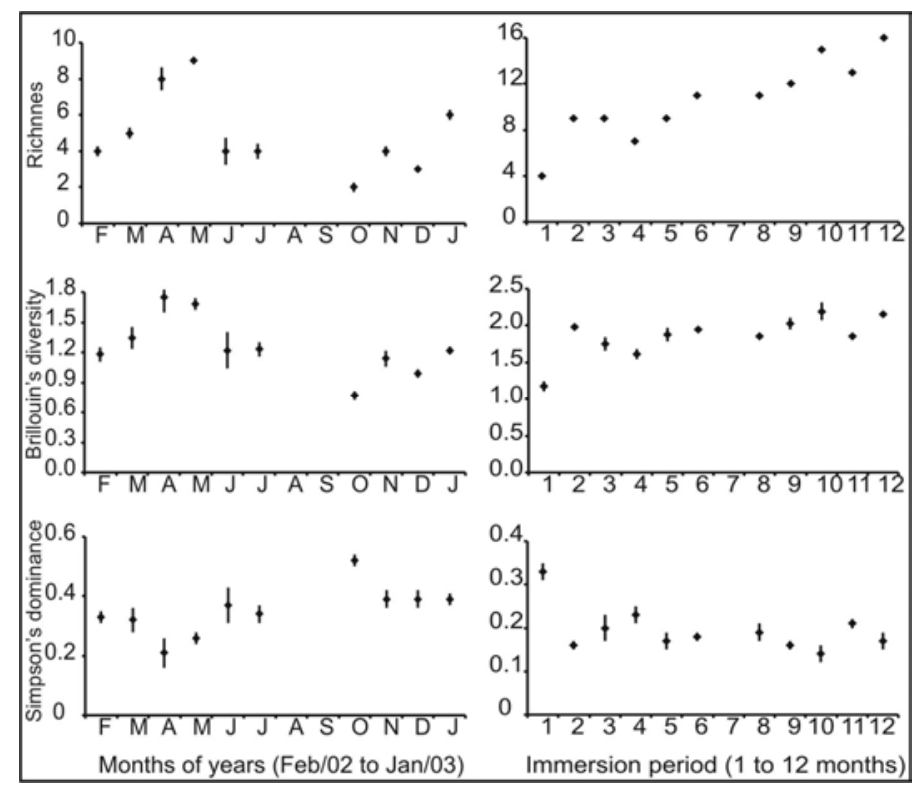

Figure 2 - Temporal variation of taxa richness $(\mathrm{N})$, Brillouin's diversity $(\mathrm{H})$ and Simpson's dominance (S) in recruitment (left side - monthly) and succession (right side cumulative) plates during the study period (mean values and standard error of four plates). 


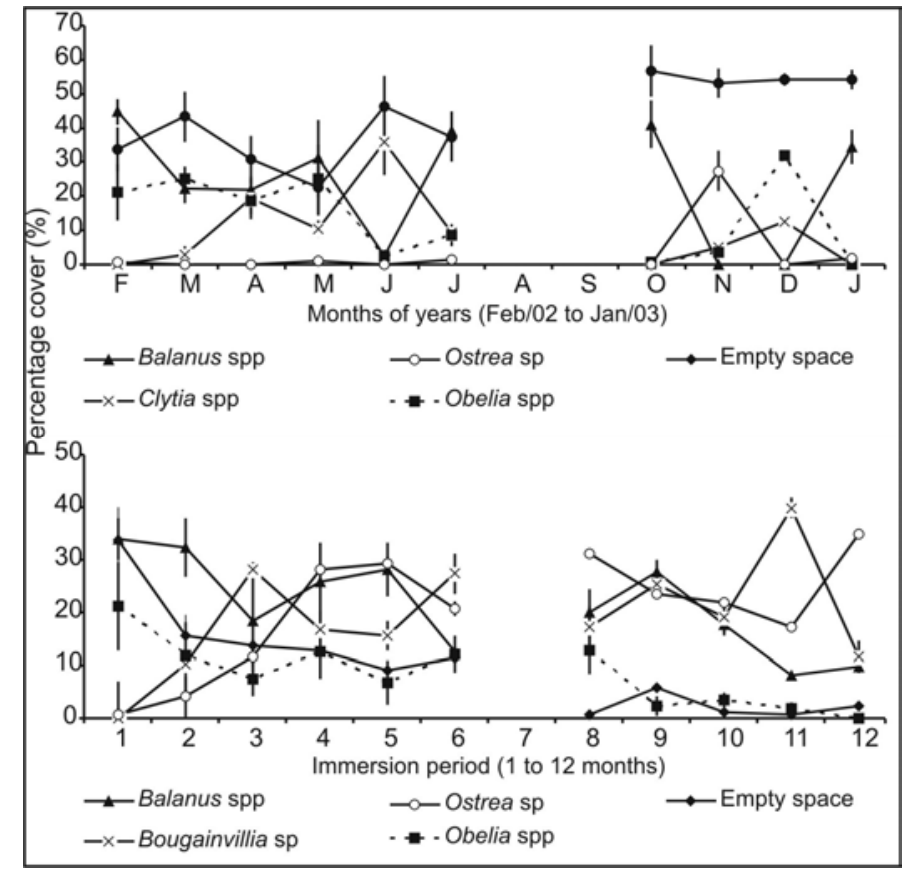

Figure 3 - Monthly variation of percentage cover of the dominant taxa and empty space on recruitment (top - monthly) and sucessional (bottom - cumulative0 plates (mean values and standard error of four plates).

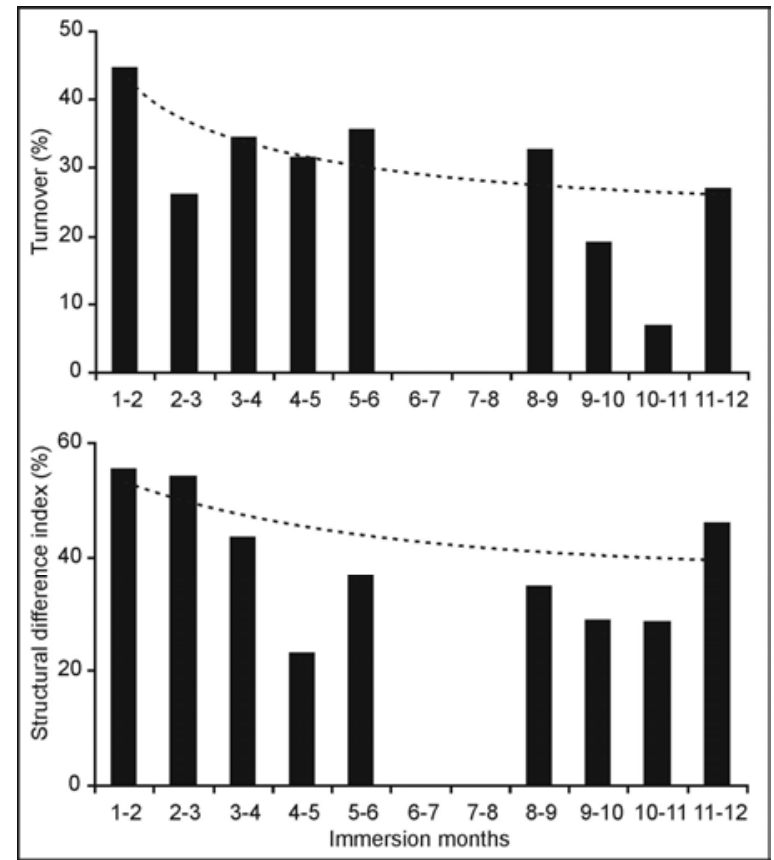

Figure 4 - Turnover rate, Structural difference index and tendency line between successive immersion months. 
The PCA analysis revealed two main groups (Fig. 5). The first one was influenced by the predominance of Balanus spp, Obelia spp and empty space in the $1^{\text {st }}$ and $2^{\text {nd }}$ months. The second group included all the other months $\left(3^{\text {rd }}\right.$ to $12^{\text {th }}$ months) and was characterized mainly by Ostrea spp and Bougainvillia spp.

There was no significant correlation between the pluviometric precipitation and Paraíba do Sul River outflow in relation to the dominant taxa. However, the empty space was significantly correlated with the precipitation (i.e. more empty space during rainy months; Krohling et al., 2006). Although the interactions between the recruits and the residents were not significant, they were always positive between the same taxonomic groups (Table 1). Among the residents, Balanus spp and Obelia spp were negatively correlated with Ostrea spp and Bougainvillia spp and positively correlated with each other (Table 2).

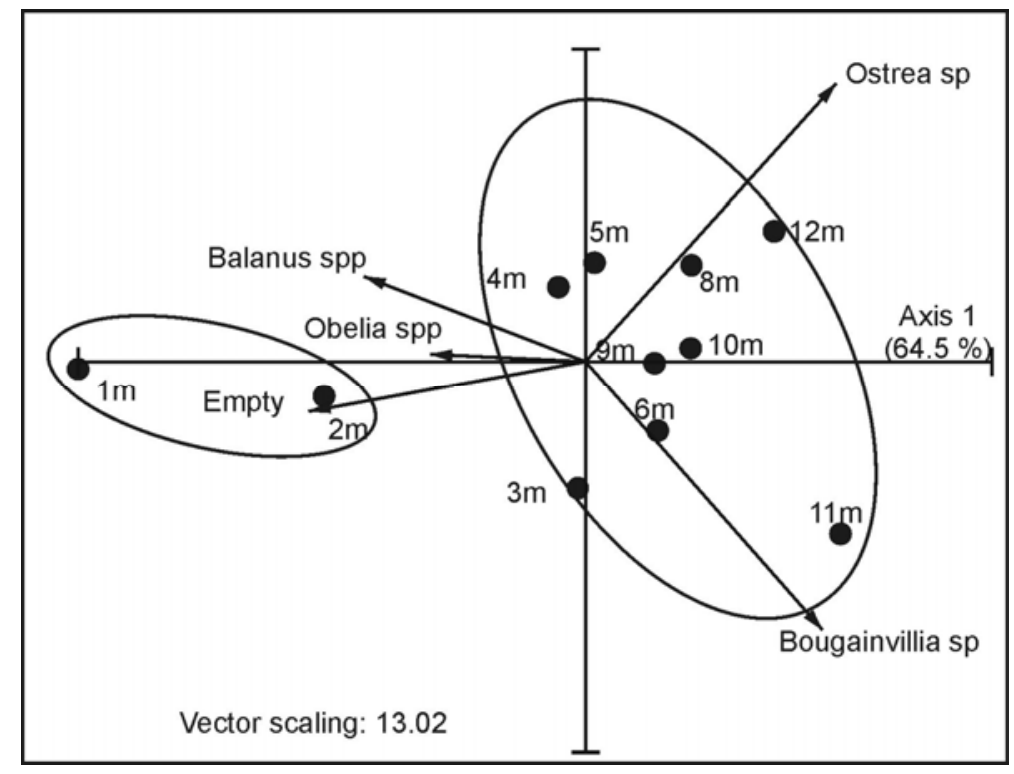

Figure 5 - PCA analysis among dominant taxa on cumulative plates (e.g. $1 \mathrm{~m}: 1^{\text {st }}$ month). Present groups are based on cluster analysis of epibenthic community (UPGMA and Morisita's coefficient).

Table 1 - Pearson's correlation of the percentage cover of dominant taxa on recruitment and cumulative plates.

\begin{tabular}{|c|c|c|c|c|c|c|}
\hline \multicolumn{7}{|c|}{ Cumulative } \\
\hline \multirow{6}{*}{ Recruitment } & & Bal. $^{1}$ & Boug. ${ }^{2}$ & Ost. $^{3}$ & Emp. ${ }^{4}$ & Obe. ${ }^{5}$ \\
\hline & Bal. $^{1}$ & 0.27 & -0.39 & -0.15 & 0.54 & 0.46 \\
\hline & Clytia spp & -0.01 & 0.27 & 0.24 & -0.13 & -0.09 \\
\hline & Obelia spp & 0.10 & 0.14 & -0.59 & 0.36 & 0.44 \\
\hline & Ostrea sp & -0.18 & -0.03 & 0.12 & -0.34 & -0.23 \\
\hline & Emp. $^{4}$ & -0.33 & 0.24 & 0.30 & -0.68 & -0.75 \\
\hline
\end{tabular}

${ }^{1}$ Balanus spp; ${ }^{2}$ Bougainvillia $\mathrm{sp} ;{ }^{3}$ Ostrea $\mathrm{sp} ;{ }^{4}$ Empty space $;{ }^{5}$ Obelia spp. 
Table 2 - Pearson's correlation of the percentage cover of dominant taxa on succession plates.

\begin{tabular}{lc}
\multicolumn{1}{c}{ Taxa } & $\begin{array}{c}\text { Pearson's correlation } \\
\text { coefficient }\end{array}$ \\
\hline Balanus spp x Bougainvillia sp & -0.65 \\
Balanus spp x Ostrea sp & -0.44 \\
Balanus spp x empty space & 0.66 \\
Balanus spp x Obelia spp & 0.58 \\
Bougainvillia sp x Ostrea sp & 0.19 \\
Bougainvillia sp x empty space & -0.58 \\
Bougainvillia sp x Obelia spp & -0.55 \\
Ostrea sp x empty space & -0.73 \\
Ostrea sp x Obelia spp & -0.51 \\
Obelia spp x empty space & 0.79 \\
\hline
\end{tabular}

\section{DISCUSSION}

The sedimentation and high turbidity are harmful to the sessile organisms during the settlement and the recruitment due to the interference with the feeding and gas exchange (Perkins, 1974; Maughan, 2001). High concentrations of the suspended material decrease the light and harm the phototrophic and heterotrophic species (Thorson, 1964), and the sediment abrasion can cause lesions in the tissues or remove the organisms from the substrate (Perkins, 1974; Anthony and Fabricius, 2000; Miller et al., 2002). Maughan (2001) compared the epibenthic community development on the concrete plates under different sedimentation conditions and found that the lowest richness and diversity occurred on the plates subjected to intense sedimenation. The sedimentation is expected to vary with the precipitation rates. However, the well-defined seasonality of Paraiba do Sul River outflow and pluviometric precipitation (ie. higher values from December to February) did not correspond to a seasonal recruitment of the epibenthic organisms. These are other physical factors that may influence the recruitment and the development of the local epibenthic community: (1) The artificial reef is located along an open coast and is subject to strong bottom currents and to an instability of hydrological features (Godoy et al., 2002); (2) The reefs are close to the substrate (within about $1.0 \mathrm{~m}$ of the bottom) resulting in a strong abrasion by sand, which may hinder the settlement of larval and spores. Therefore, physical factors such as sedimentation, turbidity, abrasion and strong currents (VanBlaricom, 1982; Miller et al., 1996) might explain the lower species abundance (maximum cover percentage $<40 \%$ on the recruitment plates), richness (mean on recruitment and the succession plates: 5 and 10 species, respectively) and the diversity (mean $\mathrm{H}$ on recruitment and succession plates: 1.3 and 1.8, respectively) in comparison to others studies in Rio de Janeiro state (Silva et al., 1989; Zalmon et al., 1993; Zalmon, 1995; Gomes and Zalmon, 2003a,b).

Empty space did not appear to be a limiting factor to the epibenthic community colonization in the studied region. The high amount of empty space probably reflected the local physical stress and low recruitment could be due to a low of "larval/spores bank". There was a general scarcity of natural hard substrate with the reproducing source populations, although balanids, serpulids, incrusting bryozoans, hydroids and colonial tunicates were often seen attached to the large drifting macroalgae.

A source of larvae and spores is very important for propagule supply for the colonization of adjacent areas, carrying out an important role in the population dynamics of benthic communities. Dispersion reduces the risk of local extinction and spreads larvae and propagules to other areas (Lotze et al., 2000; Worm et al., 2001).

Standing (1976) showed that the opportunistic character of the hydroid Obelia dichotoma (Linnaeus, 1758) (fast growth and high reproductive rates), permitting it to occupy all the available space within a few weeks and to inhibit the recruitment of Balanus in Bodega Bay, California. In the present study, these two taxa showed a positive correlation. The highest negative correlations among the dominant taxa 
were between Balanus and Ostrea (-0.44), Ostrea and Obelia (-0.51), Bougainvillia and Obelia (0.55), Balanus and Bougainvillia (-0.65). Chemical inhibitions among epibenthic species frequently occur in submerged substrates (Engel and Pawlik, 2000; Pereira et al., 2002; Pisut and Pawlik, 2002).

Concerning the interactions among the recruits and the residents, facilitation interaction was mainly observed (sensu Connell and Slatyer, 1977) among organisms of the same taxonomic category. Among the residents, an inhibition relationship occurred more frequently between the earlier (Balanus and Obelia) and later (Bougainvillia and Ostrea) dominant species. Connell (1985) suggested three factors that affected the settlement and recruitment of the benthic organisms: (1) a few planktonic propagules managed to arrive to the fixation place; (2) the water conditions adjacent to the substrate were not favorable to the establishment of the propagules and (3) the substrate was not very attractive. Probably the first and second ones had a stronger influence in the local studied due to the shortage of natural hard substrate and the adverse conditions promoted mainly by the sedimentation, currents and abrasion, which were very intense on the reef complex area. The attractive power of the substrate did not seem to be a problem to the local epibenthic recruitment. Zalmon and Gomes (2003) working nearby in a region with different substrates showed that artificial reefs made of concrete presented good conditions for the epibenthic colonization.

Chlorophyll concentrations are commonly used as a model of feeding resources. Some studies suggested a positive relation among the nutrients, primary productivity and the benthic community development (Bock and Miller, 1995; Menge et al., 1997; Brodeur et al., 1999). Souza (1998) and Godoy et.al. (2002) registered a low primary productivity (chlorophyll $a$ ) in the present area. Chlorophyll values are more expressive in Paraiba do Sul River internal estuary $(10 \mu \mathrm{g} / \mathrm{L})$. Low chlorophyll concentrations reflect less availability of the food for the epibenthic organisms, which in their majority, are represented by the suspension feeders or secondary consumers that need the primary production indirectly.

The simultaneous action of the physical (sedimentation, turbidity, abrasion, currents, lack of natural hard substrate) and biological (low primary production, shortage of a larval source) factors is suggested to cause temporal overlap in the recruitment patterns of the epibenthic species. The monthly plates reflected the available larvae in the plankton in the different months of the year, which were able to overcome these stressing factors. On cumulative plates the changes in the community structure reflected the substrate colonization history by a few resistant species and their subsequent interactions.

\section{ACKNOWLEDGMENTS}

We thanks CNPq - Conselho Nacional de Desenvolvimento Científico e Tecnológico (Processes $\mathrm{N}^{\mathrm{o}}$ 302303/2002-2, 470093/2003-0) and FAPERJ - Fundação de Amparo à Pesquisa do Estado do Rio de Janeiro (Processes $\mathrm{N}^{\circ}$ E26/171-046/96, E26/171-446/2000) for grants and scholarship.

\section{RESUMO}

A influência da sedimentação e da turbidez causadas pela precipitação pluviométrica e vazão do rio Paraíba do Sul nos meses de verão foi investigada em um recife artificial na costa norte do Estado do Rio de Janeiro, Brasil. Quatro placas de recrutamento e quarto placas de sucessão eram retiradas mensalmente (Janeiro de 2002 a Fevereiro de 2003) da superfície externa de módulos recifais de concreto. Espaço vazio não foi um fator limitante para o recrutamento. A taxa de substituição de espécies e o grau de diferença na estrutura da comunidade foram superiores nos meses iniciais, refletindo as reduzidas mudanças na dominância das espécies durante o período de estudo. A alta correlação entre precipitação e espaço vazio sugere a influência da precipitação no recrutamento e sucessão dos organismos. Recrutamento foi possível mesmo com fatores estressantes como sedimentação, turbidez, correntes de fundo e falta de substrato consolidado natural. Mudanças na estrutura da comunidade refletiram a história da colonização do substrato das poucas espécies resistentes e suas subseqüentes interações. 


\section{REFERENCES}

Anthony, K. R. N. and Fabricius, K. E. (2000), Shifting roles of heterotrophy and autotrophy in coral energetics under varying turbidity. J. Exp. Mar. Biol. Ecol., 252, 221-253.

Connell, J. H. (1985), The consequences of variation initial settlement vs. post-settlement mortality in rocky intertidal communities. J. Exp. Mar. Biol. Ecol., 93, 11-45.

Connell, J. H. and Slatyer, R. O. (1977), Mechanisms of succession in natural communities and their role in community stability and organization. Am. Nat., 111, 1119-1144.

Connell, S. D. and Glasby, T. M. (2001), Urban structures as marine habitats: an experimental comparison of the composition and abundance of subtidal epibiota among pilings, pontoons and rock reefs. Mar. Environ. Res., 52, 115-125.

Costa, F. J. L. (2003), Estratégias de gerenciamento dos recursos hídricos no Brasil: Áreas de cooperação com o Banco Mundial. Banco Mundial, Brasília..

Engel, S. and Pawlik, J. R. (2000), Allelopathic activities of sponge extracts. Mar. Ecol. Prog. Ser., 207, 273-281.

Figueiredo, R. O. (1999), Transporte de carbono e nitrogênio no baixo Paraíba do Sul: fluxos e processos. $\mathrm{PhD}$ Thesis, Universidade Estadual do Norte Fluminense, Rio de Janeiro, Brasil.

Godoy, E. A. S.; Almeida, T. C. M. and Zalmon, I. R. (2002), Fish assemblage and environmental variables on an artificial reef north of Rio de Janeiro, Brazil. $J$. Mar. Sci., 59, 138-143.

Goren, M. (1979), Succession of benthic community on artificial substratum at Elat (Red Sea). J. Exp. Mar. Biol. Ecol., 38, 19-40.

Krebs, C. J. (1989), Ecological Methodology. Harper and Row, New York.

Krohling, W.; Brotto, D. S. and Zalmon, I. R. (2006), Fouling community recruitment on an artificial reef in the north coast of Rio de Janeiro State. J. Coast. Res., 39, 1118-1121.

Lindegarth, M. (2001), Assemblages of animals around urban structures: testing hypotheses of patterns in sediments under boat-mooring pontoons. Mar. Environ. Res., 51, 289-300.

Lotze, H. K.; Worm, B. and Sommer, U. (2000), Propagule banks, herbivory and nutrient supply control population development and dominance in macroalgal blooms. Oikos, 89, 46-58.

Magurran, A. E. (1988), Ecological Diversity and its Measurement. Princeton University Press, Princeton.

Maughan, B. C. (2001), The effects of sedimentation and light on recruitment and development of a temperate, subtidal, epifauna community. J. Exp. Mar. Biol. Ecol., 256, 59-71.
Miller, D. C.; Geider, R. J., MacIntyre, H. L. (1996), Microphytobenthos: The Ecological Role of the "Secret Garden" of Unvegetated, Shallow-Water Marine Habitats. II. Role in Sediment Stability and Shallow-Water Food Webs. Estuaries, 19, 202-212.

Miller, D. C.; Muir, C. L. and Hauser, O. A. (2002), Detrimental effects of sedimentation on marine benthos: What can be learned from natural processes and rates? Ecol. Eng., 19, 211-232.

Pereira, R. C.; Carvalho, A. G.; Gama, B. A. P. and Coutinho, R. (2002), Field experimental evaluations of secondary metabolites from marine invertebrates as antifoulants. Braz. J. Biol., 62, 311-320.

Perkins, E. J. (1974), The Biology of Estuaries and Coastal Waters. Academic Press, London.

Pisut, D. P. and Pawlik. J. P. (2002), Anti-predatory chemical defenses of ascidians: Secondary metabolites or inorganic acids? J. Exp. Mar. Biol. Ecol., 270, 203-214.

Scheffer, A. (2001), Estrutura e dinâmica de comunidades epilíticas de habitats artificiais e suas relações com os fatores ambientais na plataforma rasa do estado do Paraná. PhD Thesis, Universidade Federal do Paraná, Brasil.

Skinner, L. F. and Coutinho, R. (2005), Effect of microhabitat distribution and substrate roughness on barnacle Tetaraclita stalactifera (Lamarck, 1818) settlement. Braz. Archives Biol. Technol., 48(1), 109113.

Silva, S. H. G.; Junqueira, A. O. R.; Martins-Silva, M. J.; Lavrado, H. P. and Zalmon. I. R. (1989), Fouling and wood-boring communities distribution on the coast of Rio de Janeiro, Brazil. In-Coastlines of Brazil, eds C. Neves and O. Magoon, American Society of Civil Engineers, New York, pp. 95-109

Standing, J. D. (1976), Fouling community structure: Effects of the hydroid Obelia dichotoma on larval recruitment. In-Settlement and Metamorphosis of Marine Invertebrate Larvae, ed. G. O. Mackie, Plenum Press, New York, pp. 155-164.

Sutherland, J. P. (1974), Multiple stable points in natural communities. Am. Nat., 108, 859-873.

Souza, E. G. A.; Silva, C. F.; Pereira, E. A. and Zalmon, I. R. (1998), A influência de parâmetros ambientais na distribuição de peixes capturados em recife artificial ( $\mathrm{S}$. Francisco de Itabapoana, RJ). Anais IV Simposio de Ecossistemas Brasileiros, 1, 325-332

Thorson, G. (1964), Light as an ecological factor in the dispersal and settlement of larvae of marine bottom invertebrates. Ophelia, 1, 167-208.

Underwood, A. J. and Fairweather, P. G. (1985), Intertidal communities: Do they have different ecologies or different ecologists? Procs Ecol. Soc. Australia, 14, 7-16. 
VanBlaricom, G. R. (1982), Experimental Analyses of Structural Regulation in a Marine Sand Community Exposed to Oceanic Swell. Ecol. Monogr. 52, 283305.

Worm, B.; Lotze, H. K. and Sommer, U. (2001), Algal propagule banks modify competition, consumer and resource control on Baltic rocky shores. Oecologia, 128, 281-293.

Zalmon, I. R.; Gama, B. A. P. and Leta, A. C. (1993), Fouling community organization at Guanabara Bay, Brazil: A directional process or variable temporal progression? Oebalia, 19, 217-222.

Zalmon, I R. (1995), Variabilidade temporal no agrupamento de organismos sésseis em substrato experimental na Enseada da Urca (Rio de Janeiro, Brasil): $\mathrm{O}$ papel de forças estocásticas e determinísticas. PhD Thesis, Universidade de São Paulo, Brasil.
Zalmon, I. R and Gomes, F. A. C. (2003), Comunidade incrustante em diferentes materiais de um recife artificial no litoral norte do Estado do Rio de Janeiro. Biotemas, 16, 57-80.

Zalmon, I. R. and Gomes, M. A. A. G. (2003), Comunidade incrustante em Macaé, Rio de Janeiro: Uma abordagem morfo-funcional. Bios, 11, 17-26.

Zar, J. H. (1984), Biostatistical Analysis. Prentice-Hall, New Jersey.

Received: November 28, 2005; Revised: October 24, 2006; Accepted: July 24, 2007. 